\title{
Negócios Jurídicos Processuais na Execução Civil
}

\author{
Procedural Agreements in Civil Execution Proceedings
}

\author{
Nilsiton Rodrigues de Andrade Aragão' \\ ${ }^{1}$ Universidade de Fortaleza - UNIFOR, Brasil
}

\begin{abstract}
Resumo
O objetivo principal deste trabalho é analisar a amplitude da admissibilidade de negócios processuais atípicos no cumprimento de sentença e no processo de execução. O estudo possui abordagem qualitativa, apoiada na revisão de literatura e na análise de dispositivos legais. Conclui-se houve uma efetiva ampliação do escopo dos acordos processuais nos processos de execução civil e que as hipóteses de ilegalidade do objeto são excepcionais e devem ser analisadas no caso concreto

Palavras-chave: negócios jurídicos processuais; processo de execução; gestão do processo; código de processo civil
\end{abstract}

\begin{abstract}
The main objective of this work is to analyze the amplitude of the admissibility of atypical procedural transactions without execution of judgment and without execution process. The study has a qualitative approach, supported by a literature review and analysis of legal provisions. It is concluded there was an effective expansion of the scope of Procedural agreements in civil execution proceedings and that the hypotheses of illegality of the object are exceptional and should be analyzed in the specific case.
\end{abstract}

Keywords: procedural agreements; execution proceedings; case management; civil procedure code

\section{Introdução}

A partir da cláusula geral de negociação trazida pelo art. 190 do CPC, estabeleceu-se a possibilidade de as partes adequarem o processo para atender seu interesse, valorizando a vontade privada na gestão do processo. No entanto, o potencial dessa autorização legal ainda não se manifestou em toda sua intensidade, pois o tema suscita dúvidas, entre outros pontos, sobre os limites dessa cláusula em cada tipo de procedimento.

Entre os diversos procedimentos processuais previstos na legislação, existe um grupo que é especialmente impactado por essa norma: a execução civil. O presente estudo se propõe a responder ao seguinte problema de pesquisa: qual o alcance dos negócios processuais no âmbito da execução? A pesquisa possui abordagem qualitativa, apoiada na revisão de literatura e na análise de dispositivos legais.

O artigo é relevante em termos práticos e teóricos porque a definição dos limites para celebração de negócios processuais na execução ainda é objeto de muita dúvida e divergência, o que impõe o aprofundamento e amadurecimento dos seus fundamentos, para identificar abordagens que apontem balizas mais claras para tais convenções. 
É preciso registrar já na introdução do estudo que, por ultrapassar os limites do objeto proposto, não serão enfrentadas questões que podem comprometer as condições de validade dos negócios jurídicos processuais por vícios na capacidade das partes, no respeito à forma prescrita ou não defesa em lei e na vontade livre e esclarecida. Estes aspectos serão pressupostos, para que se possa concentrar a análise no objeto da convenção processual. Por consequência, a licitude do objeto como condição do negócio jurídico é justamente a parte que se pretende abordar, tratando-se de um tema que ainda demanda maior atenção para construção de um conteúdo dogmático concreto e objetivo.

O texto está dividido em sete tópicos. O primeiro, realiza a análise da relevância o autorregramento da vontade para os procedimentos executórios e o segundo, aborda os negócios jurídicos processuais típicose atípicos na execução. Os cinco últimos tópicos se destinam, respectivamente, ao estudo de negócios processuais sobre a postulação executiva, sobre os títulos executivos, sobre as impenhorabilidades, sobre os meios executórios e sobre as regras procedimentais.

\section{A Relevância do Autorregramento da Vontade para os Procedimentos Executórios}

No Direito Processual, em especial no campo da jurisdição executiva, no qual o Estado intervém no patrimônio e na vontade das partes, é muito evidenciada a natureza pública dos institutos. Essa relação gerou historicamente uma compreensão mais restritiva na análise dos limites da atuação das partes nas definições negociadas de regras procedimentais. Não por outra razão, durante a vigência do CPC de 1973, eram raros os debates sobre o tema, e nestas poucas incursões prevalecia o entendimento contrário a tais negociações. ${ }^{1}$

É exatamente por esse contexto histórico desfavorável, que ganhou ainda mais relevo o estabelecimento de uma cláusula geral aberta para convenções processuais com o advento do CPC vigente. A legislação processual atual ampliou significativamente as manifestações da autonomia privada no processo com estímulo ao autorregramento da vontade, pelo qual se realiza uma importante faceta do princípio constitucional da liberdade (art. 5.ํㅡ da CF/1988). ${ }^{2}$

Os primeiros anos de vigência do CPC, quando o tema veio de forma intensa para a pauta dos debates acadêmicos, demonstraram a existência de uma importante margem de convenções processuais que não colide necessariamente com a conotação publicista do processo, uma vez que propostas tendentes a afastar as garantias essenciais do devido processo legal estão fora do âmbito de negociação. Ainda que de elevada abrangência, a autorização para convenções processuais respeita uma série de limites que resguardam a capacidade, a vontade e a isonomia das partes bem como a licitude do objeto e as formalidades legais.

É importante perceber que a possibilidade de negócios processuais não é uma medida isolada na legislação processual brasileira. Na verdade, ela compõe um conjunto de institutos que em diversas dimensões ressaltam a autonomia privada no âmbito processual. É, em certos termos, uma manifestação de neoliberalismo processual que flexibiliza um pouco do tradicional publicismo processual. ${ }^{3}$ Esse movimento de valorização do autorregramento da vontade é benéfico em diversos níveis, mas precisa encontrar um ponto de equilíbrio. ${ }^{4}$ A história já demonstrou existir um movimento pendular na valorização da liberdade, ora mais restritiva, ora mais extensiva. É preciso conter excessos

1 ROCHA, José Albuquerque. Teoria geral do processo. 3a ed. São Paulo: Malheiros, 1996, p. 255.

2 Na definição de Fredie Didier Jr.: "O princípio do respeito ao autorregramento da vontade no processo visa, enfim, à obtenção de um ambiente processual em que o direito fundamental de autorregular-se possa ser exercido pelas partes sem restrição irrazoáveis ou injustificadas. De modo mais simples, esse princípio visa tornar o processo jurisdicional um espaço propício para o exercício da liberdade" (DIDIER JR., Fredie. Ensaios sobre os negócios jurídicos processuais. Salvador: JusPodivm, 2018, p. 20).

3 GAJARDONI, Fernando da Fonseca. Convenções processuais atípicas na execução civil. Revista Eletrônica de Direito Processual - REDP. Ano 15. Volume 22. Número 1. Janeiro a Abril de 2021. pp, 283-321. p. 286.

4 RAATZ, Igor. Autonomia privada e processo: liberdade, negócios jurídicos processuais e flexibilização procedimental. 2a edição. Salvador: Juspodivm, 2019, p. 91. 
na utilização dos negócios processuais, para evitar retrocessos no futuro. Mesmo de forma ponderada, as possibilidades desses negócios são muitas.

Assim, os negócios processuais são mais uma forma de permitir a adequação procedimental às especificidades da causa, garantindo que o processo seja um instrumento de liberdade e segurança em prol do jurisdicionado de acordo, também, com sua compreensão do conflito. ${ }^{5}$ Essa possibilidade de acomodação formal do processo às especificidades da causa enseja uma maior aproximação das normas gerais e abstratas aos limites concretos da demanda. ${ }^{6}$ Dessa forma, o procedimento passa a ser utilizado como ferramenta de gestão judicial do conflito para potencializar a efetivação da prestação jurisdicional.

Essa adaptabilidade procedimental é especialmente relevante para as execuções, pois nestes processos é preciso perseguir o patrimônio do devedor para expropriá-lo ou coagir o executado para que ele próprio cumpra a obrigação de forma voluntária. No entanto, cada devedor possui uma realidade patrimonial e se porta de forma diferente, apresentando modos diversos de evitar ou resistir aos meios executórios. Isso faz com que as regras estabelecidas de forma geral e abstrata possam não estabelecer o caminho mais adequado para aquele caso concreto. Nesse contexto, somente por meio de negócios processuais será possível realizar um ajustamento concreto e específico para cada peculiaridade.

Admitir a adequação procedimental pela via negocial não viola as garantias do devido processo legal. O adjetivo "legal" que está associado ao devido processo é derivado do substantivo lei e, portanto, manifesta uma ideia de positividade, em consonância com o Estado Direito adotado no Brasil. Então o processo se desenvolve de forma devida quando pautado na lei. A legalidade é, assim, também um princípio constitucional que orienta o processo, por aplicação do art. $5^{\mathbf{o}}$, II, da CF $/ 88$ segundo o qual "ninguém será obrigado a fazer ou deixar de fazer alguma coisa senão em virtude de lei”. Dessa forma, quem exerce o poder jurisdicional o faz com limites. Essa é uma noção fundamental desenvolvida por séculos e hoje, felizmente, óbvia para muitos.

Todavia, o reconhecimento de uma manifestação de positividade no direito processual não enseja uma conotação de legalidade extremada e inflexível. O respeito ao devido processo legal não implica que esse processo não possa respeitar regras de instrumentalidade das formas, de adequação processual, de dispositivos de aplicação preferencial, de regras atípicas ou de outras formas de flexibilidade procedimental, pois tais situações estão previstas na lei, expressamente disciplinadas no CPC. É exatamente o que ocorre com os negócios jurídicos processuais, aos quais a própria lei estabelece um âmbito mais largo de aplicação. ${ }^{7}$

Embora a abertura negocial do processo seja geral, ela influencia também e especialmente as demandas executórias, nas quais existem diversas matérias aptas à negociação das partes para definir ônus, poderes, faculdades e deveres processuais. Nos procedimentos executórios, ainda mais que nos de cunho cognitivo, percebe-se uma elevada capacidade de adaptação procedimental para garantir a efetividade do processo. ${ }^{8}$

Ainda que a questão seja complexa e multifatorial, destacam-se três principais questões que contribuem para que a execução se torne um campo fértil para o desenvolvimento de convenções processuais: I) a natureza mais operacional do procedimento, II) a transigibilidade do direito material e III) a disponibilidade do processo de execução. A seguir explica-se cada um deles.

5 LUCCA, Rodrigo Ramina. Disponibilidade processual: a liberdade das partes no processo. São Paulo: Revista dos Tribunais, 2019, p. 39 a 43.

$6 \quad$ Na lição de Marcos Youji Minami: “O que importa agora salientar é que a cláusula de negociação processual permite uma nova abordagem do processo executivo. Ele não fica mais apenas a cargo exclusivo do Estado-Juiz. As partes podem participar ativamente dessa atividade, facilitando na solução da demanda executiva. Isso significa que atualmente qualquer análise do processo executivo jurisdicional não pode mais deixar de lado o potencial papel das partes na construção do procedimento executivo" (MINAMI, Marcos Youji. Da vedação ao non factibile: uma introdução às medidas executivas atípicas. Salvador: Juspodivm, 2019, p. 11-12).

7 RAATZ, Igor. Autonomia privada e processo: liberdade, negócios jurídicos processuais e flexibilização procedimental. 2a edição. Salvador: Juspodivm, 2019, p. 176.

8 ANDRADE, Juliana Malezzi. Negócios Jurídicos Processuais na Execução Fiscal. In: Antonio do Passo Cabral e Pedro Henrique Nogueira (Coord.) Negócios Processuais: Tomo 2. Salvador: Juspodivm, 2020, p. 569-586. P. 572. 
Ainda que os procedimentos executórios possuam indiscutível e importante atividade cognitiva ${ }^{9}$, o fato de pressuporem o reconhecimento prévio da exigibilidade da obrigação, o que corresponde ao seu objeto central, torna-o, em certos termos, mais operacional. Isso abre uma margem maior para adaptações no procedimento, seja em prol da maior efetividade ou da menor onerosidade, sem que garantias processuais fundamentais sejam violadas.

Um segundo fator merecedor de referência é o fato de que prepondera nessas demandas a transigibilidade do direito material objeto do processo. Como na maioria dos casos a questão envolve direitos meramente patrimoniais, está presente um dos pressupostos para aplicação do art. 190 do CPC. A verdade é que a noção de indisponibilidade do direito nunca foi clara, inexistindo um rol taxativo de direitos que podem ser negociados. Mesmo com o avanço da concepção de "direitos indisponíveis, mas transigíveis" a matéria continua padecendo de imprecisão conceitual. ${ }^{10}$ Em regra, os direitos são disponíveis, mas existem casos específicos que excepcionam essa diretriz, excluindo a questão do âmbito privado de decisão. ${ }^{11}$ Essas restrições são extraordinárias e devem ser restritivamente interpretadas de modo a evitar a contingência indevida da liberdade de seus titulares. Por tudo isso e considerando que o estímulo à autocomposição é um princípio do processo, a melhor interpretação da referida expressão é a de que, na dúvida, quando não existir vedação legal expressa, deve-se admitir a negociação e a autocomposição. ${ }^{12}$

Por fim, merece um destaque especial a regra de disponibilidade da execução, prevista no artigo 775 do CPC. ${ }^{13} \mathrm{O}$ legislador assegurou ao exequente a disponibilidade da execução, autorizando a desistência do processo de execução ou de medidas executórias. ${ }^{14}$ A ideia fundamental sobre esse tópico é a de que institutos processuais disponibilizados ao exequente para garantir maior efetividade ao processo podem ser por ele abdicados por estarem ligados a um interesse privado que é disponível. Somando-se a isso os princípios da instrumentalidade das formas e da efetividade processual fica mais claro que esse é o âmbito mais propício aos negócios processuais.

\section{Negócios Jurídicos Processuais Típicos e Atípicos na Execução}

Quando se estuda o autorregramento da vontade no âmbito processual, primeiramente deve-se ressaltar que o Código regula de modo expresso diversos negócios processuais. Assim, antes de ingressar no cenário mais controvertido dos negócios atípicos é preciso evidenciar os negócios processuais típicos, para os quais não se levantam maiores resistências.

Dentre estes, é possível mencionar, primeiramente, que existem manifestações unilaterais que podem se enquadrar em uma noção mais ampla de autorregramento da vontade, como é o caso da disponibilidade da execução (art. 775 do CPC) e da opção pelo parcelamento da dívida (art. 916 do CPC).

Além desses, existem diversos negócios processuais típicos bilaterais ou multilaterais, como é o caso: do modo como se deve realizar a alienação do bem (art. 730 do CPC); da eleição de foro (art. 781, I, do CPC); do pacto de impenhorabilidade (art. 833, I, do CPC); da preferência dos credores com garantias reais (art. 799, do CPC); da nomeação do executado na condição de depositário do bem penhorado (art.

9 SICA, Heitor Vitor Mendonça. Cognição do juiz na execução cível. São Paulo: Revista dos Tribunais, 2017, p.172.

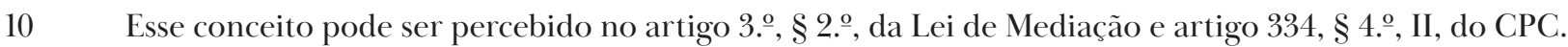

11 É o caso, por exemplo, do reconhecimento dos filhos havidos fora do casamento (art. 1.609 do CC), da disposição de tecidos, órgãos e partes do corpo humano em vida (arts. $1^{\circ}$ e $9^{\circ}$ da Lei n. 9.434/97), da adoção (art. 39, § 1º, da Lei n. 8.069/90), dos prazos prescricionais (art. 192 do CC). Ainda assim, as situações expressas são muito pontuais.

12 VENTURI, Elton. Transação de direitos indisponíveis? In: ZANETI JR., Hermes; CABRAL, Trícia Navarro Xavier (coord.). Justiça multiportas: mediação, conciliação e arbitragem e outros meios de solução adequada para conflitos. Salvador: Juspodivm, 2016. p. 405-436, p. 417-418.

13 NOGUEIRA, Pedro Henrique. Gestão da execução por meio de negócios jurídicos processuais no processo civil brasileiro. Revista de Processo, v. 286, p. 325-342, dez. 2018, p. 04.

14 NOGUEIRA, Pedro Henrique. Gestão da execução por meio de negócios jurídicos processuais no processo civil brasileiro. Revista de Processo, v. 286, p. 325-342, dez. 2018, p. 04. 
840, § 2.. , do CPC); da definição contratual de bem a ser penhorado (art. 848, II, do CPC); da escolha do depositário e da forma de administração no caso de penhora de empresa, outros estabelecimentos ou semoventes (art. 862, § 2.․․ do CPC); da escolha de depositário-administrador no caso de penhora de frutos e rendimentos de bens móveis ou imóveis (art. 869 do CPC); do acordo de avaliação do bem penhorado (art. 871, I, do CPC); da suspensão negocial da execução (art. 921, I, c/c art. 313, II, e art. 922 do CPC) etc.

A previsão expressa desses negócios torna-os menos controvertidos, apesar de igualmente importantes. Muitos deles já possuíam previsão praticamente idêntica a atual no Código anterior, ainda que não fossem comumente estudados dentro da perspectiva de uma disciplina comum. Com isso, seu entendimento e sua aplicação não suscitam maiores debates. Por essa razão, será dedica maior atenção aos negócios processuais atípicos nas execuções. ${ }^{15}$

No campo da atipicidade o tema ainda é incipiente, demandando aprofundamento doutrinário e manifestações jurisprudenciais para que se possa delinear com maior precisão quais convenções são efetivamente compatíveis com o ordenamento. Diante dos princípios do autorregramento da vontade e da liberdade das formas, a regra deve ser a de aceitação dos negócios jurídicos processuais, ou seja, na dúvida, deve-se presumir que o negócio é válido.

Se, por um lado, a atipicidade traz o benefício da abertura das hipóteses de cabimento dos negócios, por outro lado, a falta do tratamento legal expresso permite que o tema sempre seja objeto de debate. Assim, com exceção de algumas hipóteses de negócios processuais atípicos que já gozam de alguma concordância, a maioria ainda gera divergência, dentre outros motivos, por transitarem em uma área limítrofe não muito clara entre o interesse privado das partes e o interesse público que acompanha o processo.

Parte dessa resistência tem fundamento no apego a circunstâncias historicamente construídas em momentos em que não havia autorização legal expressa para tais convenções. É preciso uma reflexão sobre a matéria. Resta superado o obstáculo normativo, permanecendo tão somente uma resistência cultural, que também precisa ser transposta, mas que logicamente não é uma mudança que ocorra de forma imediata.

O tema é rico e as possibilidades são muitas, mas o cabimento não é ilimitado. Parte dos negócios processuais cogitados em hipótese causa dúvidas e levanta polêmicas. Existem convenções para as quais a doutrina já se inclina fortemente pela inadmissão, por ultrapassarem a esfera privada de disponibilidade, invadindo o âmbito do interesse público ou de prerrogativas jurisdicionais, em questões não sujeitas a transação. A matéria ainda é nebulosa, sendo difícil estabelecer um amplo rol de negócios que não podem ser realizados. Ainda assim, por exemplo, acordos tendentes a excluir punições por litigância de má-fé e por ato atentatório à dignidade da justiça, para alteração de competência executória absoluta ou para limitar de forma integral a defesa do executado, já podem ser tidos como indevidos.

Salvo em situações extremas como estas, será no caso concreto que se poderá mensurar a regularidade ou não do negócio processual. É preciso manter em mente que essas convenções pressupõem negociações prévias e que a sua aceitação muito provavelmente vem acompanhada de um bônus ou de um ônus correspondente. Há assim um equilíbrio de interesses mensurado pelas partes envolvidas na demanda, que será quebrado se o negócio for indevidamente afastado. Portanto, não há como prejulgar prejudicial o acordo simplesmente porque ele foge ao que é ordinário.

É nesse sentido que a seguir serão abordados de forma mais aprofundada alguns dos principais negócios processuais atípicos da execução. Para uma abordagem mais precisa os negócios foram organizados em cinco grupos: I) negócios processuais sobre a postulação executiva; II) negócios processuais sobre títulos executivos; III) negócios processuais sobre impenhorabilidades; IV) negócios processuais sobre meios executórios e; V) negócios processuais sobre aspectos dos ritos executórios.

15 DinamarCo, Pedro da Silva. Comentários ao Código de Processo Civil - artigos 188 a 235: da forma, do tempo e do lugar dos atos processuais. São Paulo: Saraiva Educação, 2020. p. 27. 


\section{Negócios Processuais sobre a Postulação Executiva}

O pacto de não execução (pactum de non exequendo) é uma manifestação negocial pela qual as partes deliberam por não exercitar o direito de promover uma demanda executiva. ${ }^{16}$ Trata-se de uma manifestação mais específica do pactum de non petendo, porém, essa especificidade atrai nuances que os distinguem em alguns aspectos. Inclusive afasta uma parte significa do debate sobre a incompatibilidade com o princípio da inafastabilidade da jurisdição, pois não afasta a utilização de demandas cognitivas sobre a matéria. ${ }^{17}$

A possibilidade de utilização das vias cognitivas pelo credor, mesmo quando ele dispõe de um título executivo extrajudicial, é inclusive prevista expressamente pelo CPC em seu art. 785. Essa previsão legal reforça a compatibilidade dessa matéria com o ordenamento e a possibilidade de decisão das partes a esse respeito. ${ }^{18}$

É natural avaliar a utilidade prática de uma cláusula dessa natureza, uma vez que traria pouco ou nenhum benefício imediato ao credor. No entanto, existem situações como naquelas decorrentes de relações familiares ou em casos de dificuldades financeiras nas quais a cobrança diferenciada da dívida pode estimular o seu cumprimento espontâneo. ${ }^{19}$

Apesar da liberdade negocial reconhecida no Código, é preciso ter cautela com possíveis excessos na construção da cláusula. As convenções processuais sobre a postulação executiva não podem inviabilizar toda e qualquer forma de cobrança de uma dívida, abrangendo, além das vias executórias, as demandas cognitivas e as extrajudiciais, de forma irrestrita. É por isso que o parágrafo único do art. 190 do CPC permite que o juiz recuse aplicação em casos de nulidade ou de inserção abusiva em contrato de adesão ou em que alguma parte se encontre em manifesta situação de vulnerabilidade.

Uma primeira distinção necessária para o bom entendimento do instituto é a de que o pactum de non exequendo não implica em renúncia ao direito de crédito. São situações distintas. O instituto ora estudado tem natureza processual, ao passo que a renúncia se encontra no plano do direito material. ${ }^{20}$ Com isso, o crédito continua existindo, mas eventuais cobranças devem ser efetivadas por vias extrajudiciais ou precedidas de cognição judicial, por meio de ação monitória, ou ainda utilizado para fins de compensação.

Outro fator que pode reduzir a resistência ou o questionamento sobre o negócio é a delimitação material ou temporal. No âmbito material é possível restringir parcialmente a demanda executória, impedindo, por exemplo, tutelas provisórias ou medidas processuais específicas, o que será analisado nos tópicos seguintes. ${ }^{21}$ É o caso, por exemplo, do credor que se compromete a não promover a execução do crédito por um período específico enquanto são realizadas negociações visando uma solução

16 SILVA, Paula Costa e. Pactum de non petendo: exclusão convencional do direito de ação e exclusão convencional da pretensão material. In: CABRAL, Antonio do Passo; NOGUEIRA, Pedro Henrique Pedrosa (Coord.). Negócios processuais. $3^{\text {a }}$ ed. Salvador: Juspodivm, 2017, p. 451 e ss.

17 MENDONÇA NETO, Delosmar de; GUIMARÃES, Luciano Cezar Vernalha. Negócio jurídico processual, direitos que admitem a autocomposição e o pactum de non petendo. Revista de Processo, São Paulo, v. 42, n. 272, out. 2017. p. 419-439.

18 ARAÚJO, José Henrique Mouta. Comentários ao art. 785 do CPC. In: WAMBIER, Teresa Arruda Alvim et. al. Breves comentários ao novo código de processo civil. 3ª ed. São Paulo: RT, 2016, p. 2012.

19 RENNER, Rafael. Execução negociada: possibilidades e limites das convenções processuais na tutela executiva Cível. São Paulo: Dialética, 2021, p. 312.

20 Nesse sentido a lição de Paula Costa e Silva: "Em consequência das considerações já aduzidas, parece evidente que este tipo de negócios jurídicos não incide sobre o próprio direito de crédito, aqui residindo a sua principal distinção em face da remissão, bem como a sua utilidade dogmática. Poder-se-ia dizer, porém, que é afectado o direito de exigir judicialmente o cumprimento, enquanto faculdade compreendida na situação jurídica de Direito material”. (COSTA E SILVA. Paula. Pactum de non petendo: exclusão convencional do direito de acção e a exclusão da pretensão material. In: CABRAL, Antonio do Passo; NOGUEIRA, Pedro Henrique (Org.). Negócios processuais. Salvador: Juspodivm, 2015. p. 305).

21 TRIGO, Alberto Lucas Albuquerque da Costa. Pactum de non petendo parcial. Revista de Processo. vol. 280/2018. p. 19-39. p. 23. 
autocompositiva. Ainda que não seja indispensável à validade da convenção processual, a delimitação da cláusula pode se apresentar como mais um elemento de adequação.

\section{Negócios Processuais sobre Títulos Executivos}

Algumas das mais polêmicas hipóteses de convenções processuais na execução referem-se à negociabilidade em torno dos títulos executivos. O ponto central da controvérsia está na compreensão da tipicidade legal dos títulos executivos (nulla executio sine titulo), o que, para uma corrente, implica a impossibilidade de os requisitos legais caracterizadores do título serem definidos por acordo de vontades. ${ }^{22}$

A questão é polêmica, mas a conclusão favorável a esses negócios parece manter consonância com a autorização legislativa do art. 190 do CPC. ${ }^{23}$ Partindo da premissa da disponibilidade da pretensão executiva (art. 775 do CPC) e da eficácia dos atos das partes (art. 200 do CPC), não há razão para excluir esse tema do âmbito de incidência da cláusula geral de negociação processual. ${ }^{24}$ Isso não implica uma violação ao princípio da indispensabilidade do título executivo, já que ele continua sendo exigido para deflagrar a execução, apenas amplia-se a sua fundamentação para admitir a convencional.

Para melhor compreender os impactos desses negócios processuais, é importante analisar as suas principais formas de manifestação. Uma primeira situação possível é aquela utilizada para atribuir eficácia executiva a contratos que não se enquadrem expressamente nas hipóteses do artigo 784 do CPC. ${ }^{25}$ Em outras palavras, trata da possibilidade de criar negocialmente um título executivo. ${ }^{26}$

A despeito da possibilidade jurídica de tais negócios, a amplitude do rol de títulos executivos previstos na legislação brasileira minimiza a sua necessidade, mostrando-se mais seguro adequar o título a uma das situações já disciplinadas. É o caso, por exemplo, do contrato particular, para o qual pode ser menos problemático conseguir a assinatura de duas testemunhas (art. 784, III, do CPC) do que enfrentar o debate sobre a validade de uma cláusula que atribui força executiva sem elas. No entanto, se houver interesse das partes em resguardar amplo sigilo ao objeto da avença, não há motivo para lhes negar a utilização da referida cláusula. De modo geral, os eventuais problemas devem ser avaliados concretamente.

Por fim, um dos aspectos que mais gera crítica a esses negócios é a insegurança na sua constituição, pois a falta dos requisitos legais poderia acarretar excessos e desequilíbrios, em especial nos contratos de adesão. Ainda assim, não se observa nessa questão obstáculo à aceitação dos negócios processuais. O parágrafo único do artigo 190 do CPC estabelece claramente a possibilidade de controle de validade

22 Sobre esse questionamento, conclui Fernando da Fonseca Gajardoni: "A resposta é negativa, pois, mesmo em relação aos títulos executivos extrajudiciais, o art. 784, XII, dispõe que somente terão essa qualidade os documentos que a lei, por disposição expressa, atribuir força executiva, sem abrir qualquer margem à convenção das partes” (GAJARDONI, Fernando da Fonseca; DELLORE, Luiz; ROQUE, Andre Vasconcelos; OLIVEIRA JR., Zulmar Duarte de. Execução e recursos: comentários ao CPC de 2015. São Paulo: Método, 2017, p. 66). No mesmo sentido: AURELLI, Arlete Inês. Análise e limites da celebração de negócios jurídicos processuais. In: Marcato, Ana et al (Org.). Negócios processuais. Salvador, Juspodivm. 2017, p. 62.

23 Essa possibilidade vem sendo admitida por autores como Fredie Didier Jr., Leonardo Carneiro da Cunha, Paula Sarno Braga e Rafael Alexandria de Oliveira: "É realmente muito difícil conceber um argumento que justifique a proibição de criação de títulos executivos por deliberação negocial, à luz do CPC-2015. Mesmo o art. 784, CPC, que considera título executivo aqueles a que a lei, por disposição expressa, atribuir força executiva precisa ser compreendido à luz do sistema do próprio Código: o art. 190 pode ser considerado uma fonte de autorização para a criação de outros títulos executivos" (DIDIER JR., Fredie. Curso de direito processual civil: Execução. V. 5. 11ª . ed. Salvador: Juspodivum, 2021. p. 262).

24 DiNAMARCO, Pedro da Silva. Comentários ao Código de Processo Civil - artigos 188 a 235: da forma, do tempo e do lugar dos atos processuais. São Paulo: Saraiva Educação, 2020. p. 75.

25 CÔRTES, Estefania. Negócios jurídicos processuais: mecanismo apto à atribuição de exequibilidade a um título. In: Antonio do Passo Cabral e Pedro Henrique Nogueira (Coord.) Negócios Processuais: Tomo 2. Salvador: Juspodivm, 2020, p. 541-568. P. 559.

26 CÂMARA, Alexandre Freitas. Novo processo civil brasileiro. $3^{\underline{a}}$ ed. São Paulo: Atlas, 2017, p. 343. 
das definições ilegais ou abusivas constantes desses negócios. Assim, não há fragilidade na segurança jurídica que inviabilize a proposta.

Outra manifestação possível de negócios jurídicos sobre os títulos executivos éa de estabelecimento de condições à exequibilidade de um título, o que pode ocorrer, por exemplo, com a definição de um documento obrigatório complementar, não exigido na lei, para que se possa mover a execução. Ela pode também retratar uma opção de segurança adicional para a propositura da execução, com o estabelecimento da necessidade de prévia tentativa de autocomposição extrajudicial, de notificação extrajudicial ou de protesto.

Uma terceira situação que pode ser mencionada é o estabelecimento de uma convenção processual pela qual se extrai o efeito executivo de um título executivo reconhecido como tal na legislação. Na prática, essa cláusula retrata uma decisão das partes em submeter eventual conflito futuro a um processo de conhecimento antes da execução. ${ }^{27}$ É uma forma de manifestação do pactum de non exequendo, o qual já foi tratado no item anterior.

Uma última questão que pode ser suscitada para debate nesse tópico diz respeito à impossibilidade de se atribuir a um título extrajudicial a condição de título judicial, atraindo para a satisfação do crédito o rito integral do cumprimento de sentença. Aqui há um problema que torna o negócio inviável.

A impossibilidade desse negócio se justifica pela menor margem de defesa do executado no procedimento de cumprimento de sentença. Essa característica do procedimento decorre da possibilidade que o executado tem de arguir outros temas por ocasião da fase de conhecimento, o que não ocorrerá se a fase de conhecimento não existir. Dessa forma, a mudança de procedimento violaria a garantia do contraditório e da ampla defesa do executado.

\section{Negócios Processuais sobre Impenhorabilidades}

É possível falar ainda em negócios processuais em torno das impenhorabilidades, outro campo que envolve bastante debate.

Para esse ponto, o primeiro aspecto que precisa ser analisado é o da natureza das impenhorabilidades: se de interesse público ou privado. Existem manifestações do STJ indicando que se trata de matéria de ordem pública e, portanto, inafastável pela vontade das partes. ${ }^{28}$ No entanto, com exceção dos bens inalienáveis, todas as demais hipóteses de impenhorabilidade retratam questões de típico interesse privado, dentro da área de disponibilidade do executado, tanto que os bens relacionados poderiam ser alienados pelo próprio executado para o pagamento da dívida. ${ }^{29}$

O objeto da penhora é amplo, posto que a regra é a penhorabilidade dos bens (art. 789 do CPC). Somente categorias de bens específicas declaradas como impenhoráveis ou inalienáveis não estão sujeitas à penhora (art. 832 do CPC). O fundamento axiológico das impenhorabilidades é, em essência, a própria responsabilidade patrimonial do executado, destinando-se à proteção do mínimo existencial do devedor.

A evolução humanística da execução impede que outros direitos do executado sejam atingidos, ainda que indiretamente. Embora a penhorabilidade de bens mantenha relação com o direito

27 RENNER, Rafael. Execução negociada: possibilidades e limites das convenções processuais na tutela executiva Cível. São Paulo: Dialética, 2021, p. 371.

28 STJ; REsp 1940297/MG, Rel. Ministra NANCY ANDRIGHI, TERCEIRA TURMA, julgado em 21/09/2021, DJe $28 / 09 / 2021$.

29 No mesmo sentido são as lições de Fredie Didier Jr. e Antonio do Passo Cabral "Ora, se é disponível, o bem poderia ser vendido pelo executado livremente. Se o bem pode ser alienado pela vontade do executado, por que não poderia ser penhorado (ato preparatório de futura expropriação judicial) pela vontade do próprio executado? Se o executado pode desfazer-se do bem extrajudicialmente, por que não poderia desfazer-se dele judicialmente?" (DIDIER JR., Fredie; CABRAL, Antonio do Passo. Negócios jurídicos processuais atípicos e execução. Revista de Processo, São Paulo, n. 275, jan. 2018. p. 193228). 
fundamental à tutela efetiva, existem outros direitos fundamentais de igual importância que obstam que a execução incida sobre direitos do executado de cunho não patrimonial. Em outras palavras, as impenhorabilidades destinam-se a garantir a dignidade da pessoa natural e a manutenção da pessoa jurídica. É nessa linha de raciocínio que se sustenta que a matéria seria de ordem pública e, portanto, integralmente fora da área de disponibilidade das partes.

Não obstante, inexiste norma que estabeleça de forma expressa que as impenhorabilidades se encontram fora da área de negociação ou mesmo que lhes atribuam a condição de direitos indisponíveis. Ademais, o CPC atual deu à matéria tratamento diferente em relação ao Código anterior, suprimindo do caput do art. 833 o termo "absolutamente", contido no art. 649 do CPC/73.

Uma das consequências diretas dessa mudança foi a compreensão de que a matéria comporta uma margem maior de interpretação. Ficou superada a concepção cogente das impenhorabilidades que antes predominava. Some-se a isso o fato de o próprio Código, no art. 833, I, já autoriza a celebração de negócio processual para ampliação das impenhorabilidades. Portanto, o CPC já indica ser possível a celebração de negócios processuais sobre a matéria.

Adotando esta última posição, por entendê-la mais coerente com o contexto atual do Código, é possível cogitar três hipóteses de negócios processuais no âmbito das impenhorabilidades: I) a criação de impenhorabilidades não previstas no rol do Código; II) a exclusão de uma hipótese específica de impenhorabilidade e; III) o estabelecimento de uma condição à impenhorabilidade.

A primeira hipótese trata de um negócio jurídico pelo qual os contratantes pré-excluem determinado bem de futura execução. Essa deliberação só vincula os contratantes, sendo irrelevante para execuções promovidas por terceiros alheios à avença. O art. 833, I, do CPC já autoriza expressamente esse negócio, tratando-se de um negócio processual típico. ${ }^{30}$

A segunda hipótese é a mais controvertida, por atrair de forma mais intensa o debate inicialmente apresentado. Trata da renúncia a uma impenhorabilidade prevista na lei. Não é possível presumir de modo geral que toda renúncia à impenhorabilidade acarreta necessariamente o comprometimento da vida digna do devedor e de sua família. A violação à dignidade do devedor e de sua família, a situação de vulnerabilidade ou o vício de vontade que podem macular o negócio processual devem ser analisados no caso concreto.

Porfim,épossível cogitar do estabelecimento de condições para oexercíciodasimpenhorabilidades. O bem continuará impenhorável, mas para que tal condição possa ser alegada é preciso que se configure uma situação previamente ajustada, como por exemplo a existência de outros bens penhoráveis ou a decorrência de um prazo específico. ${ }^{31}$

\section{Negócios Processuais sobre Meios Executórios}

Outro grupo de convenções processuais nas execuções que merece referência nesse estudo diz respeito àqueles que tenham por objeto os meios executórios.

Existe entendimento no sentido da impossibilidade desses negócios, sob o fundamento de que a definição das medidas executórias se encontra no campo das prerrogativas do Estado-juiz e, portanto, fora da esfera negocial. ${ }^{32}$ Todavia, se a coerção e a sub-rogação necessárias à satisfação forçada da

30 Enunciado n. 153 das Jornadas de Direito Processual Civil do CJF: "A penhorabilidade dos bens, observados os critérios do art. 190 do CPC, pode ser objeto de convenção processual das partes”.

31 De acordo com Pedro Henrique Nogueira: "Não se trata aqui de ampliar as impenhorabilidades ou mesmo de restringi-las, mas sim de disciplinar consensualmente como esse direito subjetivo processual haverá de ser exercido...” (NOGUEIRA, Pedro Henrique. Negócios jurídicos processuais. 3. ed. Salvador: Juspodivm, 2018, p. 301).

32 Assim defendem Fredie Didier Jr. e Antonio do Passo Cabral: “As partes não podem deliberar, por convenção, que o juiz não utilizará alguns meios de coerção para pressionar o litigante a cumprir uma decisão (não podem, v.g., limitar o valor das astreintes; não podem também impedir ou limitar a aplicação de multas para sancionar a litigância de má-fé). É que o uso da multa pecuniária não só diz respeito a prerrogativas do Estado-juiz para emprestar às suas decisões a efetividade 
obrigação se manifestam exatamente em prol do interesse do exequente, não há motivo para excluí-las da decisão das partes. ${ }^{33}$

Os negócios processuais, nesses casos, podem se destinar a: I) limitar a utilização de certos meios executórios; II) ampliar o cabimento de meios executórios para além de sua destinação ordinária; ou III) definir qual ou quais serão os meios executórios, típicos ou atípicos, empregados no processo.

Inicialmente, quanto à limitação negocial dos meios executórios, não há, em princípio, maiores problemas. Se o exequente pode renunciar ao próprio crédito objeto da execução, não há motivo para que não possa também renunciar antecipadamente à utilização de um desses meios executórios, ou desistir incidentalmente de algum que esteja em execução.

Nesse ponto, é válido destacar que a disponibilidade da execução, prevista no artigo 775 do CPC, dispõe expressamente que o exequente pode desistir "de apenas alguma medida executiva", previsão normativa que dá subsídio direto ao entendimento.

Existem diversos outros dispositivos que indicam margens de interferência das partes na escolha do meio executório. É o caso da regra que estabelece que o exequente deve indicar na petição inicial do processo de execução a espécie de execução de sua preferência, quando por mais de um modo puder ser realizada (art. 798, II, “a”). De modo similar, na execução de obrigação de prestar alimentos compete ao exequente a escolha da forma de execução: se por expropriação, desconto em folha ou prisão civil. Pode ser apontado ainda a autorização para indicação de bem à penhora (arts. 524, VII, 798, II, "c", 829, $\S 2^{\circ}, 835, \S 3^{\circ}$ do CPC) e as regras relativas à modificação da penhora (art. 848 do CPC). O art. 730 do CPC aponta a possibilidade de acordo sobre o modo como se deve realizar a alienação do bem. Por fim, é possível citar também uma série de meios executórios que dependem de requerimento expresso do exequente para que possam ser utilizados, como é o caso, por exemplo, do protesto de título executivo judicial (art. 517), da penhora de dinheiro em depósito ou aplicação financeira (art. 854 do CPC) e da prisão civil e desconto em folha anteriormente mencionados, entre outros.

Sob esses fundamentos, entende-se possível, por exemplo, definir por acordo que não será realizada penhora de determinado bem ou de dinheiro em depósito ou aplicação financeira ou sobre a remuneração do devedor, mesmo que nos limites autorizados pela lei. ${ }^{34}$ Esses casos podem ser enquadrados no próprio pacto de impenhorabilidade anteriormente tratado, só que visto por outra perspectiva.

É cabível também celebrar negócios processuais sobre astreintes, tratando de diversos aspectos de sua incidência, como, por exemplo, definir a não utilização desse meio executório, estabelecer o valor e a periodicidade de sua incidência, definir um limite temporal de sua incidência ou um teto para a quantia consolidada decorrente de sua aplicação etc. ${ }^{35}$

A multa por ausência de pagamento tempestivo do art. 523, $\S 1^{\circ}$, do CPC, mesmo compondo o próprio procedimento do cumprimento de sentença, é uma medida executória coercitiva, e como tal, passível de celebração de acordo. Há certo dissenso quanto à natureza desta multa. A doutrina divide-se entre os que vislumbram apenas um caráter coercitivo e os que percebem uma natureza híbrida, pela qual, concomitantemente com a coerção, a multa destinar-se-ia a punir o devedor. ${ }^{36} \mathrm{O}$

necessária” (DIDIER JR., Fredie; CABRAL, Antonio do Passo. Negócios jurídicos processuais atípicos e execução. Revista de Processo, São Paulo, n. 275, jan. 2018, p. 193-228).

33 No escólio de Pedro Henrique Nogueira: "O Estado-juiz não pode impor ou compelir o exequente a executar, ou a adotar essa ou aquela medida executiva que não lhe convenha. Por consequente, muitas possibilidades se abrem à negociação das medidas executivas com o executado em face desse regime jurídico" (NOGUEIRA, Pedro Henrique. Negócios jurídicos processuais. 3. ed. Salvador: Juspodivm, 2018, p. 303).

34 TEMER, Sofia; ANDRADE, Juliana Melazzi. Convenções processuais na execução: modificação consensual das regras relativa à penhora, avaliação e expropriação de bens. In: Coletânea mulheres no processo civil brasileiro - negócios processuais (Coordenadores Ana Marcato et al). Salvador: Juspodivm, 2018, p. 558.

35 PEREIRA, Rafael Caselli. A multa judicial (astreinte) e o CPC/2015. 2. ed. rev. e ampl. Porto Alegre: Editora Livraria do Advogado, 2018, p. 355.

36 Nesse sentido, afirmam Fredie Didier Jr., Leonardo Carneiro da Cunha, Paula Sarno Braga e Rafael Alexandria de Oliveira: "Além de medida de coerção, a imposição de multa revela-se como medida punitiva: é hipótese de sanção legal pelo 
caráter coercitivo do instituto é mais evidente, pois essa multa revela-se como importante ferramenta de convencimento do executado para o pagamento tempestivo, desencorajando a procrastinação. Com a devida vênia, a natureza sancionatória não parece compor a essência do instituto, mesmo de modo secundário. O fato de a aplicação da multa ocorrer de uma única vez não é fundamento suficiente para o reconhecimento do caráter punitivo, pois existem multas coercitivas de aplicação singular, comum na execução de obrigações de não fazer, o que não altera sua natureza coercitiva. Portanto, pode ser objeto de negociação.

É possível cogitar, ainda, o estabelecimento negocial de um limite de tempo mais curto a eventual prisão civil do devedor de alimentos. Ora, se o exequente pode optar por não escolher este meio executório ou de requerer sua revogação a qualquer tempo, nada impede que seja celebrado negócio estabelecendo limites. ${ }^{37}$

Outro ponto que pode ser sugerido é a vedação da utilização de meios executórios atípicos. As partes podem julgar relevante que os meios executórios sejam mantidos no âmbito daqueles já definidos na legislação para garantir uma maior previsibilidade.

No estudo desse tema, é preciso lembrar ainda que algumas medidas executórias são invasivas e inquietantes, envolvendo situações aflitivas que podem se chocar com interesses tidos pelas partes como mais importantes que a própria relação obrigacional objeto da demanda. Esses elementos normalmente não se apresentam nos autos, mas são relevantes para os litigantes, uma vez que compõem a lide sociológica. É o caso, por exemplo, da prisão civil ou da penhora de um imóvel específico com valor sentimental. Daí a importância de permitir que as partes interfiram nessa decisão.

Como se percebe, as possibilidades são muitas, mas é necessário ponderar os efeitos limitativos que tais negócios geram para a execução. A restrição negocial da utilização de meios executórios pode acarretar uma menor efetividade da execução, o que pode ocasionar uma demora na conclusão do processo ou até mesmo dar ensejo à prescrição intercorrente (art. 921 do CPC). Dessa forma, ela deve ser muito bem pensada e construída, utilizando-se sempre que possível de mecanismos compensatórios.

Prosseguindo no estudo desse tópico, passa-se a analisar a situação oposta, ou seja, a utilização dos negócios processuais para fins de ampliação dos meios executórios. Nesse segundo ponto, a questão atrai maior debate e precisa ser avaliada com cautela.

Uma primeira forma de ampliar o rol de medidas executivas disponíveis se dá por meio da utilização de meios executórios típicos, mas que possuem hipóteses de cabimento restritas para situações específicas, comunicando meios executórios de procedimento distintos. É o caso, por exemplo, dos meios diferenciados previstos para as execuções de alimentos. Em princípio, não se vislumbram maiores impedimentos para a utilização do desconto em folha de pagamento ou da constituição de capital para o cumprimento de uma obrigação civil não alimentar de cunho continuado, por fundamentos já apresentados nos tópicos anteriores. Já no caso da prisão civil a mesma lógica não pode ser aplicada, uma vez que o ordenamento traz mais restrições à limitação da liberdade de locomoção para o pagamento de dívidas, vigorando assim as limitações decorrentes da responsabilidade patrimonial do executado (art. $5^{\mathrm{o}}$, LXVII, da CF/88). ${ }^{38}$

Ainda nesse ponto, é possível ampliar os meios executórios por meio da prévia autorização para utilização de meios executórios atípicos, afastando as discussões acerta da possibilidade e da adequação daquele meio executório indicado.

A última espécie de negócios processuais sobre meios executórios é aquele destinado à definição prévia de um meio executório, preestabelecendo a ordem de meios executórios que o juiz deverá utilizar. Como o próprio Código expressa a possibilidade de celebração de acordo sobre o modo como se deve

inadimplemento da obrigação”. (DIDIER JR., Fredie; CUNHA, Leonardo Carneiro da; BRAGA, Paula Sarno; OLIVEIRA, Rafael Alexandria de. Curso de direito processual civil: execução. 11ª . ed. Salvador: Juspodivum, 2021. v. 5, p. 518).

37 RENNER, Rafael. Execução negociada: possibilidades e limites das convenções processuais na tutela executiva Cível. São Paulo: Dialética, 2021, p. 433.

38 ARAGÃO. Nilsiton Rodrigues de. A utilização da prisão civil como meio executório atípico. In: Medidas executivas Atípicas - Grandes temas do Novo CPC. 2ª ed. 2020. 
realizar a alienação do bem (art. 730 do CPC) ${ }^{39}$, não há impedimento em se estabelecer negocialmente, por exemplo, a priorização da alienação antecipada de bens ou da adjudicação, tão logo efetivada a constrição. ${ }^{40}$ Mais do que priorizar uma forma específica de expropriação, é possível também vedar a utilização de alguma modalidade expropriativa. ${ }^{41}$

O fundamento para essa possibilidade não se distancia muito da renúncia a meios executórios, pois se o exequente pode renunciar a uma medida específica, também poderá colocá-la em uma ordem diferente de prioridade. O Código já autoriza isso em casos específicos, como, por exemplo, na hipótese em que as partes celebram negócio para estabelecer uma garantia real, que terá prioridade na penhora inclusive em relação ao dinheiro (art. 835, § 3º, do CPC). De modo similar, é viável o estabelecimento de um benefício de ordem de origem negocial de modo, por exemplo, a priorizar o patrimônio de um codevedor em relação ao de outro. ${ }^{42}$ É possível, ainda, modificar a ordem preferencial de bens penhoráveis, ainda que seja para afastar a prioridade dada a penhora de dinheiro pelo $§ 1^{\circ}$ do art. 835 do CPC. ${ }^{43}$

Essa questão traz para o debate a possibilidade de se afastar negocialmente a regra de subsidiariedade na utilização dos meios executórios atípicos. A ideia por traz desse requisito de aplicação de meios atípicos é o fato de que a previsão legal e a regulamentação mais detalhada da forma de efetivação dos meios executórios típicos garantem maior segurança na condução do processo. Essa previsibilidade e segurança podem ser garantidas por meio de uma previsão negocial, de modo que não faria sentido continuar a exigir uma aplicação subsidiária. ${ }^{44}$

\section{Negócios Processuais sobre Aspectos dos Ritos Executórios}

Existem outros diversos aspectos dos procedimentos executórios que podem ser objeto de negociação por se enquadrarem na definição de ônus, poderes, faculdades e deveres processuais, conforme estabelecido no art. 190 do CPC.

A averbação premonitória é um instrumento para cientificação geral da pendência de processo no registro de um bem com a finalidade de conferir a cientificação de terceiros de que o bem em questão foi ou poderá ser atingido pela execução, viabilizando a configuração de fraude à execução. Assim, ainda que a averbação não implique na intransmissibilidade do bem, ela pode tornar mais difícil negociálo diante do risco de ineficácia da alienação em relação ao exequente. Dessa forma, é possível que o exequente e o executado pactuem a proibição da averbação na matrícula ou no registro de determinado bem. Se é possível celebrar o pacto de impenhorabilidade, excluindo um bem específico do âmbito de incidência da penhora, nada impede que se proíba a averbação premonitória do mesmo por convenção das partes.

As regras do cumprimento provisório de sentença também podem ser objeto de acordo das partes. Como sua utilização depende de requerimento do exequente, não resta muita dúvida que ele possa negociar sobre isso. ${ }^{45}$ Nesse ponto, é possível abordar a própria utilização do instituto, com uma cláusula que estabeleça que somente é admitida a execução de decisões judiciais transitadas em julgado.

39 ZANETTI, Pedro Ivo Gil. Revisão contratual e negócios processuais. São Paulo: Almedina, 2019 , p. 86.

40 CÂMARA, Helder Marinoni. Negócios jurídicos processuais: condições, elementos e limites. São Paulo: Almedina, 2018, p 158.

41 NOGUEIRA, Pedro Henrique. Negócios jurídicos processuais. 3. ed. Salvador: Juspodivm, 2018, p. 537.

42 DIDIER JR., Fredie; CABRAL, Antonio do Passo. Negócios jurídicos processuais atípicos e execução. Revista de Processo, São Paulo, n. 275. p. 193 a 228. Jan. 2018, p. 206.

43 Enunciado 417 da Súmula do STJ: "Na execução civil, a penhora de dinheiro na ordem de nomeação de bens não tem caráter absoluto".

44 ZANETTI JR., Hermes. Comentários ao Código de Processo Civil. Vol. XIV. São Paulo: Thomson Reuters, 2018, p.

112.

45 TAVARES, João Paulo Lordelo Guimarães. Da admissibilidade dos negócios jurídicos processuais no Novo Código de Processo Civil: aspectos teóricos e práticos. Revista de Processo. Vol. 254. Pp, 91-109. Abr. 2016, p. 99. 
Em certos termos, equivaleria a permitir que as partes estabeleçam pela via negocial um efeito suspensivo não previsto na legislação. É possível ainda modificar as hipóteses de exigência ou de dispensa da caução, tornando, por exemplo, mais claros os conceitos jurídicos indeterminados utilizados pelo Código nesse ponto ("grave dano" e "situação de necessidade"). Pode ainda estabelecer a forma de caução que será aceita, por exemplo, autorizando expressamente caução fidejussória ou exigindo caução real, afastando com isso possível discussão sobre a idoneidade dela. ${ }^{46}$

Também é viável a celebração de acordo para aplicação do pagamento parcelado no cumprimento de sentença. É certo que por expressa disposição do artigo 916, § 7.․․, do CPC, o parcelamento não se aplica ao cumprimento de sentença, entre outros motivos, a restrição se justifica para garantir a máxima efetividade à atividade executória e por compatibilidade lógica com a multa do $§ 1$ 1. $^{\circ}$ do artigo 523 do $\mathrm{CPC}$, o que pode não ser a via mais vantajosa para o exequente. ${ }^{47}$ Todavia, se o exequente que é o destinatário dos benefícios oriundos dessa limitação concordar, não há motivo para impedir que as mesmas regras do artigo 916 sejam utilizadas no cumprimento de sentença, aproveitando os limites já definidos na lei. Assim, o executado que em princípio não possuiria um direito ao parcelamento passa a tê-lo.

É possível cogitar ainda a viabilidade de convenção das partes para estabelecer o valor mínimo aceito na alienação judicial. Essa é uma questão especialmente delicada e que costuma gerar debates no processo. Assim, para afastar de forma prévia eventuais questionamentos, as partes podem já definir um percentual específico com base no valor da avaliação, estabelecer um patamar mínimo diferenciado para a definição do juiz, ou definir critérios objetivos para guiar a manifestação judicial. ${ }^{48}$ Como ocorre em muitas das hipóteses analisadas, o tema não é pacífico, já existindo manifestação da jurisprudência no sentido de reconhecer o caráter público dessa matéria e, portanto, colocando-a fora da área de decisão das partes. ${ }^{49}$

Por fim, é possível ainda cogitar de realização de calendário processual. Essa pode ser uma ferramenta negocial bastante efetiva na execução, em especial quando inserida no contesto da execução de obrigações não pecuniárias complexas que precisam ser cumpridas em diferentes e sucessivas etapas. ${ }^{50}$

Enfim, o intuito nesse tópico não foi o de exaurir as possibilidades, mas de demostrar por meio de alguns aspectos procedimentais que os negócios processuais podem se mostrar úteis para o ajustamento das partes.

\section{Conclusão}

Em resposta ao problema de pesquisa, identifica-se que sim, há uma ampla margem para a utilização de negócios jurídicos processuais e pré-processuais entre exequente e executado, seja ele destinado a ampliar a eficiência da execução ou para tornar a execução menos onerosa ou invasiva.

Ficou demonstrado que os negócios processuais permitem adequar os procedimentos executórios, permitindo que o procedimento seja utilizado como ferramenta de gestão do processo, atendendo de forma precisa às especificidades da causa e dos litigantes, além de preservar uma maior previsibilidade na tramitação processual.

46 ZANETTI, Pedro Ivo Gil. Revisão contratual e negócios processuais. São Paulo: Almedina, 2019 , p. 87.

47 Essa posição é viável por ser a multa coercitiva, como entende BUENO, Cassio Escarpinella. Comentários Código de Processo civil. Vol. X. São Paulo: Saraiva, 2018, p. 212.

48 TEMER, Sofia; ANDRADE, Juliana Melazzi. Convenções processuais na execução: modificação consensual das regras relativa à penhora, avaliação e expropriação de bens. In: Coletânea mulheres no processo civil brasileiro - negócios processuais (Coordenadores Ana Marcato et al). Salvador: Juspodivm, 2018, p. 564.

49 TJSP, Agravo de Instrumento n. 2191919-20.2018, 15 $5^{\mathbf{a}}$ Câmara de Direito Privado, Rel. Juiz José Wagner Peixoto, j. 04.10.2018.

50 AURELLI, Arlete Inês. Análise e limites da celebração de negócios jurídicos processuais. In: Marcato, Ana et al (Org.). Negócios processuais. Salvador, Juspodivm. 2017, p. 60. 
Ressalte-se, por fim, que qualquer desses negócios processuais está submetido ao controle de validade pelo juiz que deverá, no caso concreto, analisar o atendimento aos requisitos. O negócio processual, para ser válido precisa versar sobre direito que admita autocomposição, ter partes capazes, não registrar situação de vulnerabilidade em qualquer dos polos, além de ser lícito, determinado e possível. Contudo, tais análises não podem ser pressupostas ou presumidas de modo a limitar previamente a celebração de negócios processuais. O controle judicial só pode ser realizado no caso concreto.

\section{Referências}

ANDRADE, Juliana Malezzi. Negócios Jurídicos Processuais na Execução Fiscal. In: Antonio do Passo Cabral e Pedro Henrique Nogueira (Coord.) Negócios Processuais: Tomo 2. Salvador: Juspodivm, 2020, p. 569-586.

ARAGÃO. Nilsiton Rodrigues de. A utilização da prisão civil como meio executório atípico. In: Medidas executivas Atípicas - Grandes temas do Novo CPC. 2ª ed. 2020.

ARAÚJO, José Henrique Mouta. Comentários ao art. 785 do CPC. In: WAMBIER, Teresa Arruda Alvim et. al. Breves comentários ao novo código de processo civil. 3aㅡ ed. São Paulo: RT, 2016.

AURELLI, Arlete Inês. Análise e limites da celebração de negócios jurídicos processuais. In: Marcato, Ana et al (Org.). Negócios processuais. Salvador, Juspodivm. 2017.

BUENO, Cassio Escarpinella. Comentários Código de Processo civil. Vol. X. São Paulo: Saraiva, 2018.

CÂMARA, Alexandre Freitas. Novo processo civil brasileiro. $3^{\underline{a}}$ ed. São Paulo: Atlas, 2017.

CÂMARA, Helder Marinoni. Negócios jurídicos processuais: condições, elementos e limites. São Paulo: Almedina, 2018.

CÔRTES, Estefania. Negócios jurídicos processuais: mecanismo apto à atribuição de exequibilidade a um título. In: Antonio do Passo Cabral e Pedro Henrique Nogueira (Coord.) Negócios Processuais: Tomo 2. Salvador: Juspodivm, 2020, p. 541-568.

COSTA E SILVA. Paula. Pactum de non petendo: exclusão convencional do direito de acção e a exclusão da pretensão material. In: CABRAL, Antonio do Passo; NOGUEIRA, Pedro Henrique (Org.). Negócios processuais. Salvador: Juspodivm, 2015.

DIDIER JR., Fredie. Curso de direito processual civil: Execução. V. 5. 11ª. ed. Salvador: Juspodivum, 2021.

DIDIER JR., Fredie. Ensaios sobre os negócios jurídicos processuais. Salvador: JusPodivm, 2018.

DIDIER JR., Fredie; CABRAL, Antonio do Passo. Negócios jurídicos processuais atípicos e execução. Revista de Processo, São Paulo, n. 275. p. 193 a 228. Jan. 2018.

DINAMARCO, Pedro da Silva. Comentários ao Código de Processo Civil - artigos 188 a 235: da forma, do tempo e do lugar dos atos processuais. São Paulo: Saraiva Educação, 2020.

GAJARDONI, Fernando da Fonseca; DELLORE, Luiz; ROQUE, Andre Vasconcelos; OLIVEIRA JR., Zulmar Duarte de. Execução e recursos: comentários ao CPC de 2015. São Paulo: Método, 2017.

GAJARDONI, Fernando da Fonseca. Convenções processuais atípicas na execução civil. Revista Eletrônica de Direito Processual - REDP. Ano 15. Volume 22. Número 1. janeiro a abril de 2021. pp, 283321.

LUCCA, Rodrigo Ramina. Disponibilidade processual: a liberdade das partes no processo. São Paulo: Revista dos Tribunais, 2019.

MENDONÇA NETO, Delosmar de; GUIMARÃES, Luciano Cezar Vernalha. Negócio jurídico processual, direitos que admitem a autocomposição e o pactum de non petendo. Revista de Processo, São Paulo, v. 42, n. 272, out. 2017. 
MINAMI, Marcos Youji. Da vedação ao non factibile: uma introdução às medidas executivas atípicas. Salvador: Juspodivm, 2019.

NOGUEIRA, Pedro Henrique. Gestão da execução por meio de negócios jurídicos processuais no processo civil brasileiro. Revista de Processo, v. 286, p. 325-342, dez. 2018.

NOGUEIRA, Pedro Henrique. Negócios jurídicos processuais. 3. ed. Salvador: Juspodivm, 2018.

PEREIRA, Rafael Caselli. A multa judicial (astreinte) e o CPC/2015. 2. ed. Porto Alegre: Editora Livraria do Advogado, 2018.

RAATZ, Igor. Autonomia privada e processo: liberdade, negócios jurídicos processuais e flexibilização procedimental. 2ª edição. Salvador: Juspodivm, 2019.

RENNER, Rafael. Execução negociada: possibilidades e limites das convenções processuais na tutela executiva Cível. São Paulo: Dialética, 2021.

SICA, Heitor Vitor Mendonça. Cognição do juiz na execução cível. São Paulo: Revista dos Tribunais, 2017.

SILVA, Paula Costa e. Pactum de non petendo: exclusão convencional do direito de ação e exclusão convencional da pretensão material. In: CABRAL, Antonio do Passo; NOGUEIRA, Pedro Henrique Pedrosa (Coord.). Negócios processuais. $3^{\underline{a}}$ ed. Salvador: Juspodivm, 2017.

TAVARES, João Paulo Lordelo Guimarães. Da admissibilidade dos negócios jurídicos processuais no Novo Código de Processo Civil: aspectos teóricos e práticos. Revista de Processo. Vol. 254. p. 91-109. Abr. 2016.

TEMER, Sofia; ANDRADE, Juliana Melazzi. Convenções processuais na execução: modificação consensual das regras relativa à penhora, avaliação e expropriação de bens. In: Coletânea mulheres no processo civil brasileiro - negócios processuais (Coordenadores Ana Marcato et al). Salvador: Juspodivm, 2018.

TRIGO, Alberto Lucas Albuquerque da Costa. Pactum de non petendo parcial. Revista de Processo. vol. 280/2018. p. 19-39.

VENTURI, Elton. Transação de direitos indisponíveis? In: ZANETI JR., Hermes; CABRAL, Trícia Navarro Xavier (coord.). Justiça multiportas: mediação, conciliação e arbitragem e outros meios de solução adequada para conflitos. Salvador: Juspodivm, 2016. p. 405-436.

ZANETTI JR., Hermes. Comentários ao Código de Processo Civil. Vol. XIV. São Paulo: Thomson Reuters, 2018.

ZANETTI, Pedro Ivo Gil. Revisão contratual e negócios processuais. São Paulo: Almedina, 2019. 